\title{
Diet and sexual segregation of bighorn sheep (Ovis canadensis mexicana Merriam) in Sonora, Mexico
}

\author{
Gastelum-Mendoza, Fernando Isaac ${ }^{1}$; Tarango-Arámbula, Luis Antonio ${ }^{1^{*}}$; Olmos-Oropeza, Genaro ${ }^{1}$; \\ Palacio-Núñez, Jorge ${ }^{1}$; Valdez-Zamudio, Diego $^{2}$, Noriega-Valdez, Roberto ${ }^{3}$ \\ ${ }^{1}$ Colegio de Postgraduados, Campus San Luis Potosí, Postgrado de Innovación en Manejo de Recursos \\ Naturales, Salinas de Hidalgo, San Luis Potosí, México. \\ ${ }^{2}$ Universidad de Sonora, Colonia Centro, Hermosillo, Sonora, México. \\ ${ }^{3}$ Unidad de Manejo para la Conservación de la Vida Silvestre Rancho Noche Buena, Hermosillo, Sonora, \\ México. \\ *Corresponding author: 1tarango@colpos.mx
}

\begin{abstract}
Objective: To determine the diet of the bighorn sheep and identify differences in its composition between sexes and periods (reproductive and segregation).

Design/methodology/approach: The study was conducted at the UMA Rancho Noche Buena, Hermosillo, Sonora, Mexico. To determine the plant species in the bighorn sheep feces the micro histological technique and a cell catalog of plants from the study area were used. From the diet information, the relative frequency, the Shannon-Weaver diversity index and the Kulczynski similarity index by sex and period (reproductive and segregation) were determined.

Results: The diet of the bighorn sheep included 40 plant species, being herbaceous $(36.1 \pm 4.4 \%)$ and grasses $(26.8 \pm 8.9 \%)$ the most common. The male diet during the segregation period was mainly composed of grasses (36.2\%) and female diet by herbaceous (30\%) and grasses (29.8\%). There were no differences in the diversity of the diets in males and females during the segregation period $\left(H^{\prime}=1.0\right)$, overall, their diets were very similar (80\%).

Limitations/implications: Collect a greater number of fecal samples by sex and period (reproductive and segregation) and to analyze the nutritional content of the plants consumed by bighorn sheep.

Findings/conclusions: In this study, the sexual segregation exhibited by the bighorn sheep was not due to food preferences.
\end{abstract}

Key words: diversity, fecal sample, similarity.

Citation: Gastelum-Mendoza, Fernando Isaac; Tarango-Arámbula, Luis Antonio, Olmos-Oropeza, Genaro, Palacio-Núñez, Jorge, Valdez-Zamudio, Diego, \& NoriegaValdez, Roberto. (2021). Diet and sexual segregation of the bighorn sheep (Ovis canadensis mexicana Merriam) in Sonora, Mexico. Agro Productividad, 14(\#). https:// doi.org/10.32854/agrop.v14i6.2043

Editor in Chief: Dr. Jorge Cadena Iñiguez

Estimated publication date: July 2021

This work is licensed under a Creative Commons Attribution-NonCommercial 4.0 International license (c) $(5)$

\section{INTRODUCTION}

The bighorn sheep (Ovis canadensis mexicana M.) is a species that has high ecological and economic values. However, illegal hunting, habitat destruction and competition with exotic and feral species have restricted the distribution of their populations to the state of Sonora (Wehausen, 1996; Creeden and Graham, 1997). The Official Mexican Norms classify it as a species subject to special protection (Diario Oficial de la Federación [DOF], 2010). This species has developed survival strategies, specifically sexual segregation, which occurs at the end of the reproductive season when the groups of adult males separate from the groups of females, offspring, and juveniles (Bleich et al., 1997; Barboza and Bowyer, 2000). It is established that during segregation, males, to regain their body condition (after the reproduction period) and establish dominance over other males, require higher food diversity and of better nutritional quality. In contrast, females select safer sites, but with low forage abundance and lower nutritional quality (Main et al., 1996; Tarango et al., 2002). The sexual segregation exhibited by wild 
herbivores has implications on nutrient cycling, ecological succession and species diversity in the ecosystems (Bowyer et al., 2001; Espinosa et al. 2006; Jansen et al., 2009).

Although bighorn sheep has been widely studied in the United States (FestaBianchet, 1988; Wehausen, 1996; Bowyer et al., 2001; McKinney and Smith, 2007), in Mexico the reported research works for this species are few (Tarango et al., 2002; Guerrero et al., 2003; Guerrero-Cárdenas et al., 2016). In this regard, in Sonora, it has been documented that during the segregation period male and female diets were similar, indicating that this behaviour was not related to food preferences (Tarango et al., 2002). Understanding the causes of sexual segregation is important to implement specific habitat management and improvement actions for males and females (Bowyer et al., 2001; Pérez-Barbería et al., 2007). Therefore, the objective of this study was to identify the composition of the bighorn sheep's diet by sex and period (reproductive and segregation) in the Wildlife Conservation Management Unit (UMA) Rancho Noche Buena at Hermosillo, Sonora, Mexico. In this study, it was assumed that the composition of the diet of males and females during the period of sexual segregation was different.

\section{MATERIALS AND METHODS}

The study was conducted from August 2014 to August 2015, at the Wildlife Conservation Management Unit (UMA) Rancho Noche Buena ( $29^{\circ} 07^{\prime} 58.67^{\prime \prime} \mathrm{N}, 112^{\circ} 02^{\prime} 11.48^{\prime \prime} \mathrm{W}$ ), located at Hermosillo, Sonora, Mexico (Figure 1). It has a 5,063-ha extension, an aridwarm climate, an elevation between $200 \mathrm{~m}$ and $800 \mathrm{~m}$.a.s.l. In it, bighorn sheep inhabits and is used as a game species. The dominant vegetation type is microphyllous desert scrub. The mean annual precipitation is $365.7 \mathrm{~mm}$, with rains from July to September, the average relative humidity is $43 \%$ and mean annual temperature $24.8^{\circ} \mathrm{C}$, with a maximum of $48.5^{\circ} \mathrm{C}$ in August and a minimum of $-4^{\circ} \mathrm{C}$ in January (López et al., 1999).

\section{Diet composition and diversity}

The micro histological technique was used to identify the composition of the diet of the bighorn sheep. It consists of comparing and quantifying the plant structures included in a reference catalog and the observed structures in fecal samples of bighorn sheep (Fracker and Brischle, 1944; Sparks and Malechek, 1968, Holechek et al., 1982).

To prepare the catalog, plant species samples were collected from the bighorn sheep distribution sites within the study area. These were classified by biological form (shrubs, arboreal, herbaceous, grasses and succulents), family and species. Sheep feces were collected in field trips during the reproductive period (only during May 2015 due to the sheep hunting season) and the sexual segregation period (October 2014, June and July 2015), during which the sheep were observed and located with Leica ${ }^{\circledR} 15 \times 56$ binoculars, at distances of between $700 \mathrm{~m}$ and $900 \mathrm{~m}$. Once the sheep were located, they were followed with a Swarovski ${ }^{\circledR} 60 \times 85$ telescope, until they were seen defecating. Subsequently those feces were collected, each sample was recorded, noting the date, sex, period, and then processed in the laboratory. 


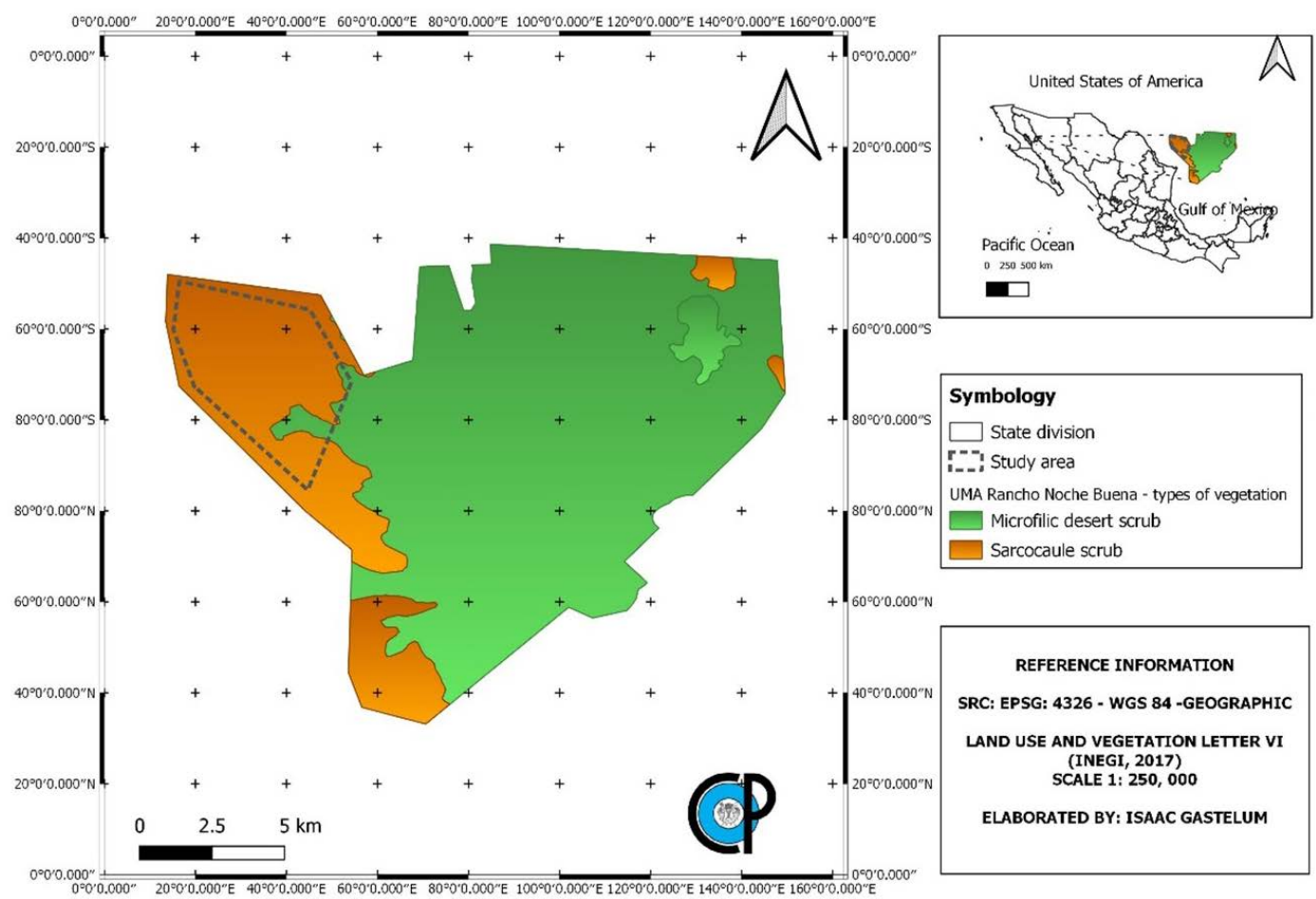

Figure 1. Location and types of vegetation in the UMA Rancho Noche Buena, municipality of Hermosillo, Sonora, Mexico.

The assessment of the bighorn sheep diet was done by collecting, preparing and analyzing seven samples from males and 12 from females during the reproductive period and five samples from males and nine from females during the segregation period. From each fecal group, classified by sex and period, a composite sample was prepared for micro histological analysis. From each sample, five slides were prepared and ten fields per slide were observed with a Leica ${ }^{\circledR}$ DM 4000B microscope with 10X objective and 10X ocular.

The species percentage within the diet by sex and period was calculated by relative frequency following Fracker and Brischle (1944). Species diversity in the diet was calculated using the Shannon-Weaver index (1949). To determine the degree of similarity between diets by sex and period, the Kulczynski index (1928) was calculated using the Past 3.0 statistical software.

\section{RESULTS AND DISCUSSION}

The bighorn sheep diet, considering the two periods, reproductive and segregation, was composed of 40 species grouped in 20 families. It has been documented that bighorn sheep in northern latitudes consume a greater number of species. For example, in the northern United States and southern Canada, a consumption of more than 200 species is reported (Brown et al., 1977; Seegmiller and Ohmart 1981). In contrast, in Arizona (Krausman et al., 1989) and California (Seegmiller and Ohmart, 1981) a bighorn sheep diet with a smaller number of plants (58 and 32, respectively) has been recorded. In 
Caborca, Sonora, Mexico, the sheep consumed 41 species (Tarango et al., 2002), in Baja California Sur 47 (Guerrero et al., 2016) and in Coahuila 49 species (Gastelum, 2020).

Males consumed 31 species and females consumed an equal number, from which, nine species were consumed only by males and another nine only by females (Table 1 ). Males during the reproductive period consumed more herbaceous species (38.6\%) and in the segregation period more grasses (36.2\%) (Figure 2).

The females during the segregation period mainly consumed herbaceous (30\%) and grasses (29.8\%); and more herbaceous in the reproductive period (47.6\%) (Figure 2). During the segregation period, Aristida adscensionis (Figure 3) predominated in male (20.7\%) and female diets (27.2\%) (Table 1$)$.

Although the diet of males and females in the segregation period was similar (IS=80), grasses were more important for males. In this regard, Ruckstuhl and Neuhaus (2000) mention that the digestive tract of males is more adapted to digest fibrous food with a low digestibility percentage, such as grasses (Figure 3). This has also been documented in other bovids, such as the American bison (Bison bison L.) in Kansas, United States (Post et al., 2001).

The composition of the diet of wild herbivores depends on the availability of forage (Morrison et al., 1992). For example, in the Sonoran Desert and much of North America, shrub species represent the sheep's diet basis because they are available throughout the year (Sandoval, 1979; Watts, 1979; Leopold and Krausman, 1991). In addition to shrubs, the grasses that sprout annually are species preferred by sheep, mainly because of their nutritional content and a high digestibility (Tarango et al., 2002; McKinney and Smith, 2007). In this regard, during the reproductive period, the consumption of herbaceous plants by males and females increased, since it is in spring when the regrowth of these annual plants begins; during this period, males and females used the steepest portions of the mountains, where the humidity conditions in the canyons favor their availability. Although the female diet was the most diverse during the reproductive period $\left(\mathrm{H}^{\prime}=1.2\right)$, no differences were observed between their diets and that of males in the segregation period $\left(\mathrm{H}^{\prime}=1.0\right)$ (Figure 2).

The greater diet diversity in the reproductive period could be due to the rain's onset in May and the greater forage availability (López et al., 1999). The diet similarity was greater (IS=96) between males in the segregation period and females in the reproductive period (Table 2). In contrast, the diet of segregated males and males in the reproductive period registered greater differences (IS=67) (Table 2). 
Table 1. Composition of the diet of male and female bighorn sheep by family, species, and period in the UMA Rancho Noche Buena, Sonora, Mexico.

\begin{tabular}{|c|c|c|c|c|c|}
\hline \multirow{2}{*}{ Family } & \multirow{2}{*}{ Species } & \multicolumn{2}{|c|}{ Reproductive period (\%) } & \multicolumn{2}{|c|}{ Segregation period (\%) } \\
\hline & & Males & Females & Males & Females \\
\hline \multicolumn{6}{|l|}{ Trees } \\
\hline Fabaceae & Acacia willardiana & 2.2 & 1.7 & 4.7 & 9.8 \\
\hline Burseraceae & Bursera microphylla & 0.7 & 0.8 & & 0.9 \\
\hline Fabaceae & Cercidium microphyllum & 9.7 & 9.2 & 11.4 & 5.5 \\
\hline Fabaceae & Olneya tesota & 2.2 & & 0.5 & \\
\hline \multicolumn{6}{|l|}{ Shrubs } \\
\hline Burseraceae & Bursera laxiflora & 0.7 & & & \\
\hline Rhamnaceae & Colubrina glabra & 1.5 & & & \\
\hline Rhamnaceae & Condalia globosa & & 1.7 & & 0.9 \\
\hline Asteraceae & Encelia farinosa & & & & 0.9 \\
\hline Fabaceae & Hoffmannseggia densiflora & & & & 0.4 \\
\hline Labiatae & Hyptis emoryi & 0.7 & & & \\
\hline Euphorbiaceae & Jatropha cardiophylla & & & & 0.4 \\
\hline Euphorbiaceae & Jatropha cinerea & & & 0.5 & \\
\hline Euphorbiaceae & Jatropha cuneata & & & & 1.7 \\
\hline Acantahaceae & Justicia candicans & 1.5 & 5 & 1 & 1.7 \\
\hline Malvaceae & Kosteletzkya malvavizcana & & 0.8 & 0.5 & \\
\hline Krameriaceae & Krameria erecta & & & 2.6 & \\
\hline Krameriaceae & Krameria grayi & & 2.5 & & 3.8 \\
\hline Zygophyllaceae & Larrea tridentata & 0.7 & & & \\
\hline Solanaceae & Lycium brevipes & & 2.5 & & 0.4 \\
\hline Fabaceae & Mimosa laxiflora & 1.5 & 6.7 & 1.6 & 3.4 \\
\hline Fabaceae & Senna covesii & 0.7 & & & 0.9 \\
\hline Buxaceae & Simmondsia chinensis & 7.5 & 3.3 & 8.8 & 7.2 \\
\hline \multicolumn{6}{|l|}{ Forbs } \\
\hline Malvaceae & Abutilon incanum & 0.7 & 6.7 & 0.5 & 2.6 \\
\hline Amaranthaceae & Alternanthera pungens & & 0.8 & & 0.9 \\
\hline Asteraceae & Ambrosia confertiflora & & 1.7 & 2.6 & 0 \\
\hline Primulaceae & Anagallis arvensis & & 4.2 & & 1.7 \\
\hline Malvaceae & Anoda cristata & 7.5 & 14.2 & 4.1 & 2.6 \\
\hline Sapinadaceae & Cardiospermum corindum & 1.5 & 0.8 & 0.5 & \\
\hline Ranunculaceae & Clematis drummondii & 4.5 & 0.8 & 2.1 & \\
\hline Fabaceae & Dalea emoryi & 1.5 & 1.7 & & 1.3 \\
\hline Solanaceae & Datura disocolor & 0.7 & & 1.6 & \\
\hline Euphorbiaceae & Ditaxis lanceolata & 1.5 & 1.7 & 1 & 3.4 \\
\hline Asteraceae & Dyssodia concinna & 0.7 & & & \\
\hline Malvaceae & Herissantia crispa & 3.7 & 4.2 & 4.7 & 1.3 \\
\hline Malvaceae & Hibiscus denudatus & 2.2 & & 0.5 & \\
\hline Malpighiaceae & Janusia gracilis & 2.2 & 0.8 & & \\
\hline Asteraceae & Verbesina encelioides & 11.9 & 10 & 10.4 & 16.2 \\
\hline \multicolumn{6}{|l|}{ Grasses } \\
\hline Poaceae & Aristida adscensionis & 12.7 & 11.7 & 20.7 & 27.2 \\
\hline Poaceae & Bouteloua barbata & 13.4 & 3.3 & 15.5 & 2.6 \\
\hline \multicolumn{6}{|l|}{ Succulents } \\
\hline Cactaceae & Lemaireocereus thurberi & & 0.8 & 1.6 & 0.9 \\
\hline
\end{tabular}




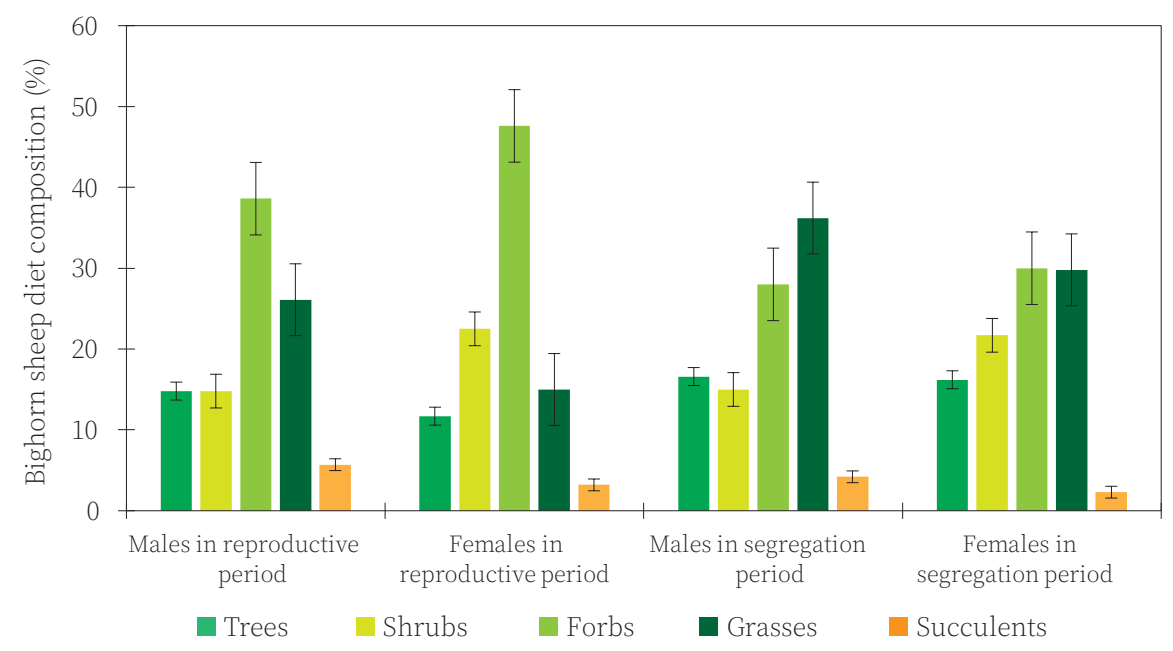

Figure 2. Composition of the bighorn sheep diet by sex, period (reproductive and segregation) and biological form at the UMA Rancho Noche Buena, Hermosillo, Sonora, Mexico.

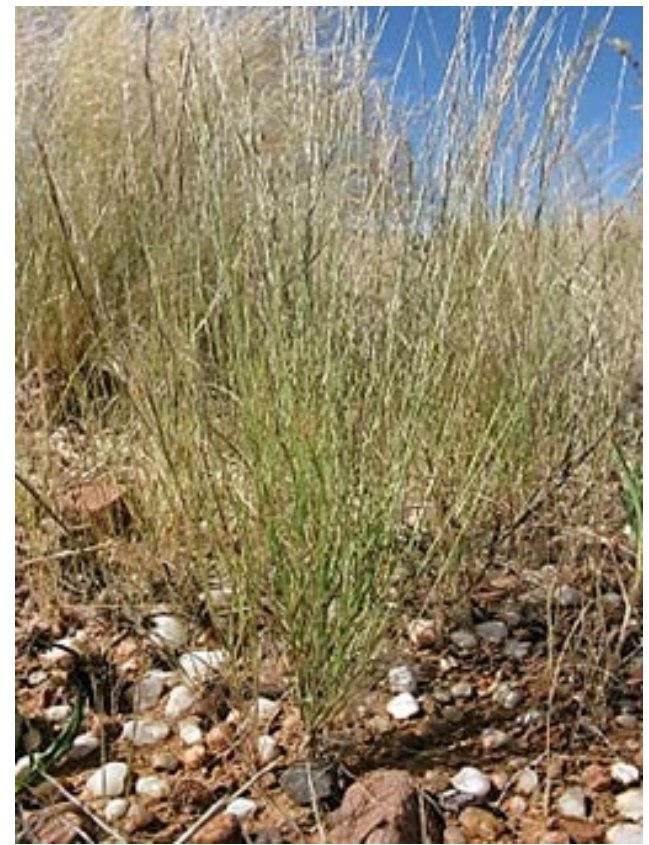

Figure 3. Zacate tres barbas (Aristida adscensionis), the most important species in the diet of the bighorn sheep at the UMA Rancho Noche Buena, Hermosillo, Sonora, Mexico (Photograph by N. Dreber).

Table 2. Percentage values of the Kulczynski similarity index (IS) in the males and females diet composition by period (reproductive and segregation) at the UMA Rancho Noche Buena, Hermosillo, Sonora, Mexico.

\begin{tabular}{l|c|c|c|c}
\hline & $\begin{array}{c}\text { Males in } \\
\text { segregation period }\end{array}$ & $\begin{array}{c}\text { Males in } \\
\text { reproductive period }\end{array}$ & $\begin{array}{c}\text { Females in } \\
\text { segregation period }\end{array}$ & $\begin{array}{c}\text { Females in } \\
\text { reproductive period }\end{array}$ \\
\hline Males in segregation period & 100 & & & \\
\hline Males in reproductive period & 67 & 100 & 100 & \\
\hline Females in segregation period & 80 & 73 & 75 & 100 \\
\hline Females in reproductive period & 96 & 89 & & 7 \\
\hline
\end{tabular}


The similarity between the diet of females in the reproductive and segregation period was IS $=75$. This can be explained by the hypothesis on segregation proposed by Main et al. (1996), who propose that females during the segregation period occupy steeper areas and with more visibility to evade predators, at the cost of a less diverse diet and lower nutritional quality. Authors such as Tarango et al. (2002), recorded that, once the reproductive season was over, the groups of males (made up of class III and IV males) separated from the females' groups (females, lambs and juvenile males). However, they indicated that, although the groups were spatially separated, they tended to use the same areas at different times (Bleich et al., 1997; Tarango et al., 2002; Pérez-Barbería et al., 2007).

This sheep behaviour during its forage activity could explain the 80\% similarity in the diet composition of males and females during the segregation period. In the present research, it was recorded that in the reproductive period the females grouped with class III or IV males, that distributed in lower places of the mountains and foraged in streams. On these sites, shrubs and grasses are more common than in the higher areas. In contrast, during the segregation period, females were in higher areas, generally alone or with other females, lambs, and occasionally juvenile males.

The above is consistent with that reported on sexual segregation in bighorn sheep (Miller and Gaud, 1989; Tarango et al., 2002). Although during the reproductive period the females tend to occupy the same sites as in the segregation period (with few plants cover and adequate visibility), males make local trips to these sites in search of reproductive females, to establish dominance and form reproductive groups. Once the reproductive period is over, they separate from the females and look for places where the forage is more abundant and of greater nutritional value (Ruckstuhl and Neuhaus, 2000; Tarango et al., 2002). This explains the greater similarity (75\%) in the female diet between periods in relation to the male diet (67\%).

The results on the similarity of the diet of males and females coincide with that reported by Miller and Gaud (1989) in Arizona, whose similarity varied between 40\% and $80 \%$. In the present study, the similarity in the diet composition of segregated males and females was 80\%, while between males (segregation period) and females (reproductive period) it was $96 \%$. As already mentioned, in the Sonoran Desert the groups of males in the reproductive period move from their foraging sites to the areas used by the females to establish reproductive groups. However, females tend to occupy the same sites regardless of the reproductive period (Tarango et al., 2002).

Based on the results of this research, the hypothesis of the present work that the composition of the diet of segregated males and females was different is rejected. The results of this study can be applied to estimate the carrying capacity in the Sonoran Desert, where the bighorn sheep is the main game species and is preferably extensively managed. It is recommended to continue with this line of research and study the forage availability by season and period, carry out bromatological analyses of the consumed plant species to know their nutritional contribution and probable deficiencies in bighorn sheep individuals. This information is essential to establish management 
programs, habitat improvement or supplementation programs according to the needs of the UMA Rancho Noche Buena and its surrounding areas.

\section{CONCLUSIONS}

Herbaceous and grasses predominated in the bighorn sheep diet. During the segregation period, males consumed mostly grasses, and females herbaceous and grasses. However, in the reproductive period, herbaceous plants were the main species in the diet of males and females. The similarity of the diets of males and females in the segregation period was high. Therefore, sexual segregation exhibited by the bighorn sheep at the UMA Rancho Noche Buena was not due to forage selection.

\section{ACKNOWLEDGMENTS}

To the staff of Rancho Noche Buena, for the provided support during the field-work phase. Likewise, to Dr. Carlos Hugo Alcalá Galván and Dra. Reyna Amanda Castillo Gámez, of the Department of Scientific and Technological Research (DICTUS), of the Universidad de Sonora, for their contribution in the creation of the reference plant catalog.

\section{REFERENCES}

Barboza, P. S., and Bowyer, R. T. (2000). Sexual segregation in dimorphic deer: a new gastrocentric hypothesis. Journal of Mammalogy 81:473-489.

Bleich, V. C., Bowyer, R. T., and Wehausen, J. D. (1997). Sexual segregation in mountain sheep: resources or predation. Wildlife Monographs 134:1-50.

Bowyer, R. T., McCullough, D. R., and Belovsky, G. E. (2001). Causes and consequences of sociality in mule deer. Alces 37:371- 402

Brown, R. W., Smith, D. D., and McQuivey, R. P. (1977). Food habits of desert bighorn sheep in Nevada, 1956-1976. Desert Bighorn Council Transactions 21:13-16.

Creeden, P. J., and Graham, V. K. (1997). Reproduction, survival, and lion predation in the Black Ridge Colorado National Monument desert bighorn herd. Desert Bighorn Council Transactions 41:37-43.

Espinosa, A. T., Sandoval, A., and Contreras, A. (2006). Historical distribution of desert bighorn sheep (Ovis canadensis mexicana) in Coahuila, Mexico. The Southwestern Naturalist 51(2):282-288.

Festa-Bianchet, M. (1988). Age-specific reproduction of bighorn ewes in Alberta, Canada. Journal of Mammalogy 69:157-160.

Fracker, S. B., and Brischle, H. A. (1944). Measuring the local distribution of ribes. Ecology 25:283-303.

Guerrero, I., Tovar, I., y Álvarez, S. (2003). Factores que afectan la distribución espacial del borrego cimarrón Ovis canadensis weemsi en la Sierra del Mechudo, Baja California Sur, México. Anales del Instituto de Biología. Universidad Autónoma de México Serie Zoología 74(1):83-98.

Guerrero, I., Gallina, S., Corcuera, P., Álvarez-Cárdenas, S., and Ramírez-Orduña, R. (2016). Diet composition and selection of the bighorn sheep (Ovis canadensis) in Sierra El Mechudo, Baja California Sur, Mexico. Therya 7 (3):423-437.

Holechek, J. L., Vavra, M. y Pieper, R. (1982). Botanical composition determination of range herbivore diets: A review. Journal of Range Management 35: 309-315.

Jansen, B. D., Krausman, P. R., Bristow, K. D., Heffelfinger, J. R., and Vos, J. C. (2009). Surface mining and ecology of desert bighorn sheep. The Southwestern Naturalist 54(4):430-438.

Krausman, P. R., Leopold, B. D., Seegmiller, R. F., and Steven, G. T. (1989). Relationships between desert bighorn sheep and habitat in western Arizona. Wildlife Monographs 53:66 
Leopold, B. D. y Krausman, P. R. (1991). Factors influencing desert mule deer distribution and productivity in southwestern Texas. Southwestern Naturalist 36: 67-74.

López, L. R., Schweinsburg, R., and Luna, S. (1999). Relación uso-disponibilidad de componentes topográficos y un modelo de calidad del hábitat para el borrego cimarrón, en Sonora, México. Acta Zoológica Mexicana 76:17-34.

Main, M. B., Weckerly, F. W., and Bleich, V. C. (1996). Sexual segregation in ungulates: new directions for research. Journal of Mammalogy 77:449-461.

McKinney, S., and Smith, T. W. (2007). Diets of adults and lambs of desert bighorn sheep during years of varying rainfall in central Arizona. The Southwestern Naturalist 52(4):520-527.

Miller, G. D., and Gaud, W.S. (1989). Composition and variability of desert bighorn diets. Journal of Wildlife Management 53: 597-606.

Morrison, M. L., Marcot, B. G. y Mannan, R. W. (1992). Wildlife habitat relationships. University of Wisconsin Press.

Pérez-Barbería, F. J., Robertson, E., Soriguer, R., Aldezabal, A., Mendizabal, M., and Pérez-Fernández, E. (2007). Why do polygynous ungulates segregate in space? Testing the activity-budget hypothesis in soay sheep. Ecological Monographs 77 (4):631-647.

Post, D., Ambrust, T., Horne, E. y Goheen, R. (2001). Sexual segregation results in differences in content and quality of bison (Bison bison) diets. Journal of Mammalogy 82(2): 407- 413.

Ruckstuhl, K. E., and Neuhaus, P. (2000). Causes of sexual segregation in ungulates: a new approach. Behaviour 137:361-377.

Seegmiller, R. F., and Ohmart, R. D. (1981). Ecological relationships of feral burros and desert bighorn sheep. Wildlife Monographs 78:58.

Shannon, C., and Weaver, W. (1949). The Mathematical Theory of Communication. University of Illinois Press, Urbana.

Sparks, D. R., and Malechek, J. C. (1968). Estimating percentage dry weight in diets using a microscope technique. Journal of Range Management 21:264-265.

Tarango, L. A., Krausman, P. R., Valdez, R., and Kattnig, R. M. (2002). Research observation: desert bighorn sheep diets in northwestern Sonora, Mexico. Journal of Range Management 55:530-534.

Watts, T. J. (1979). Detrimental movement patterns in a remnant population of bighorn sheep (Ovis canadensis mexicana). Tesis, New Mexico State University, Las Cruces, EUA.

Wehausen, J. D. (1996). Effects of mountain lion predation on bighorn sheep in the Sierra Nevada and Granite Mountains of California. Wildlife Society Bulletin 24:471-479. 